\title{
Urine protein in Systemic Lupus Erythematosus: Electrophoretic patterns and comparison of different biochemical methods of detection
}

\author{
Mohamed Khaled Mohamed $^{1 *}$, Manal Hassanein Abbas ${ }^{1}$, Abear Mohamady Abdel-Bary ${ }^{2}$ and Naglaa \\ Farouk $^{2}$ \\ Rheumatology Unit, Ain Shams University Hospitals ${ }^{1}$ and Clinical Pathology Department, Faculty of Medicine ${ }^{2}$, Ain \\ Shams University, Cairo, Egypt
}

\section{A R T ICLE INFO}

Article history:

Received 18 September 2016

Accepted 25 December 2016

Keywords:

Systemic lupus Erythematosus;

Proteinuria;

Turbidimetric;

immunoassay;

Electrophoretic pattern.

\begin{abstract}
A B S T R A C T
This study aimed to fractionate the urine protein from 84 Systemic lupus Erythematosus (SLE) patients by electrophoresis and to compare different methods of its detection. Urine protein electrophoresis was performed on agarose gel.Spot non-concentrated urine samples were used. Methods for protein detection were M1, M2, M3 and M4. M1 and M2 were two pyrogallol red dependent colorimetric methods differ in linearity and standards used. M3 is a trichloroacetic acid (TCA) turbidimetric method. M4 is a turbidimetric immunoassay for urine albumin detection. Urine protein electrophoresis (UPE) revealed 3 patterns (glomerular, tubular and mixed glomerular and tubular). Albumin/creatinine ratio ( $\mathrm{P} / \mathrm{C}$ ratio) is not valid for the detection of proteinuria in patients with pure tubular pattern of proteinuria. The ratios of proteinuria $(\mathrm{P} / \mathrm{C}$ ratio) of M3/M1, M3/M2 and M2/M1 were $0.78 \pm 0.31,0.75 \pm 0.19$ and $0.79 \pm 0.19$, respectively. These ratios showed inadequate agreement between the 3methods. This was also confirmed by regression analysis $(\mathrm{Y}(M 1)=1.7 \mathrm{X}(M 3)+27.5$, $\mathrm{Y}(M 2)=1.4 \mathrm{X}(M 3)-21.6$ and $\mathrm{Y}(M 1)=1.2 \mathrm{X}(M 2)+50.6)$. Ratios and regression analysis showed a good and better agreement between M3 and M4 for the detection of urine albumin than with M1and M2. UPE in SLE patients showed 3 patterns of proteinuria. Comparison with renal biopsy is needed to evaluate UPE as a non-invasive technique for detecting the source of proteinuria in SLE. Inadequate agreement was found between 3 methods for the detection of proteinuria. The TCA turbidimetric method showed the best for the detection of urine albumin. A good agreement was found between methods for the detection of the globulin band.
\end{abstract}

\section{Introduction}

Renal disease is a frequent complication of SLE which can lead to significant illness and even death. Lupus nephritis (LN) is a unique form of immune complex glomerulonephritis. In contrast to other glomerulonephritides, such as IgA nephropathy, postinfectious glomerulonephritis, or primary membranoproliferative glomerulonephritis, lupus nephritis is characterized by both glomerular as well as extraglomerular immune complex deposition. Extraglomerular immune complex deposits can occur in the tubular basement membranes (TBM), interstitium, $\underset{\text { p1] }}{\text { peritubular capillary walls and arterial/arteriolar walls }}$

SLE-associated tubulointerstitial injury (SLE TIN) is

\footnotetext{
* Corresponding author.

E-mail address: khaled61_m@hotmail.com
}

increasingly recognized in two forms, i.e, secondary and primary. The secondary form co-exists with lupus glomerulonephritis, whereas the primary form develops against the background of no or mild glomerular ${ }^{[2]}$. Tubulointerstitial inflammatory lesions in glomerulonephritides are an important cause of progressive renal dysfunction ${ }^{[1]}$. Thus, an accurate definition of the nature and severity of renal involvement in SLE is mandatory to assess the possible risk of progression and to establish an appropriate treatment ${ }^{[3]}$. Urine protein electrophoresis can distinguish glomerular from tubular damage by different patterns. In glomerular proteinuria electrophoretic patterns, large molecules such as albumin predominate while in tubular pattern many small globulins e.g. polyclonal free light chains and $\alpha 2-$ microglobulins predominate ${ }^{[4-6]}$. The Renal Disease Subcommittee of the American College of Rheumatology 
(ACR) recommends the protein / creatinine ratio (P/Cratio) for use in clinical trials of $\mathrm{LN}^{[7]}$, and the European League Against Rheumatism/European Dialysis and Transplant Association suggest using P/C ratio for monitoring $\mathrm{LN}^{[8]}$. The use of $\mathrm{P} / \mathrm{C}$ ratio for the quantification of proteinuria came from Ginsberg et al. [9] in 1983 who proposed the use of the ratio of the concentrations of the protein and creatinine contents in a single voided urine sample instead of 24 hours urine protein, reasoning that if the creatinine excretion remained stable, then $\mathrm{P} / \mathrm{C}$ ratio would reflect the cumulative protein excretion during a day.

However, the studies on $\mathrm{P} / \mathrm{C}$ ratio have some caveats ${ }^{[10-}$ 14]. Bland and Altman [11-12] highlighted on the inappropriate methodology in studies reporting on correlation of two methods of clinical measurement over the entire sample range. This may conceal disagreement between the 2 methods of the same sample at the extreme ranges. Chitalia et al. ${ }^{[13]}$ pointed out that the results in many studies is based on the association (correlation) between $\mathrm{P} / \mathrm{C}$ ratio and 24 hour urine protein but do not enable a reliable decision to be made to replace one with the other. Clearly, there is not complete agreement among the existing studies on the utility of $\mathrm{P} / \mathrm{C}$ ratio in screening and monitoring $\mathrm{LN}$. One of the reasons for the variance among the results of the published studies is partly related to the use of inappropriate statistical analyses ${ }^{[10]}$. Indeed, none of the studies have discussed the effect of the methods used for protein measurement and the protein contents (or fractions) on the value of urinary protein as determined by $\mathrm{P} / \mathrm{C}$ ratio.

The aim of the present study was to analysis the urine protein contents of a group of SLE patients by agarose gel electrophoresis in an attempt to identify the source of proteinuria from different distinctive patterns. Comparison between different analytical methods for of urine protein determination was performed.

\section{Subjects and methods}

A total of 84 SLE patients were enrolled in this study. Patients were either attending the outpatients' clinic or they were inpatients in the Rheumatology Department, Ain Shams University Hospitals. All patients gave informed consent to participate in the study. The baseline demographic characteristics of the study population are summarized in Table $\mathbf{1}$.

The inclusion criteria included the following: 1) SLE patients at any age and sex and 2) the presence of any degree of proteinuria. The exclusion criteria included the following: 1) absence of diabetes, pregnancy or any other condition that may produce proteinuria, 2) absence of any drug known to interfere with the methods used in this study, 3) absence of any drug that may produce drug induced lupus, 4) absence of kidney dialysis, and 5) absence of any other autoimmune disease.

Random urine specimens $(n=8 \varepsilon)$, were collected from all patients, centrifuged $(2500 \mathrm{~g}$ for $10 \mathrm{~min})$ and stored at $-20{ }^{\circ} \mathrm{C}$. Immediately before protein assay, the samples were thawed at room temperature.
Total protein in urine was determined by 3 methods, two colorimetric and one turbidimetric.

Method 1 (M1) (from Biomed Diagnostics, Egypt) is a colorimetric one according to Watanable ${ }^{[15]}$. The reagent used in this method is $0.1 \mathrm{mmol}$ pyrogallol, sodium molybdate below $1 \%$, sodium oxalate below $1 \%$ and 100 $\mathrm{mmol} / \mathrm{l}$ buffer. The standard used was albumin/globulin (50 mg/dl). Linearity is $250 \mathrm{mg} / \mathrm{dl}$ and sample volume used is $25 \mu \mathrm{l}$.

Method 2 (M2) is another colorimetric method (Chemdiagnostica, Italy) ${ }^{[\mathbf{1 5}, \mathbf{1 6}]}$. The composition of the reagent was $0.04 \mathrm{mmol}$ pyrogallol, $0.13 \mathrm{mmol}$ sodium molybdate, $1 \mathrm{mmol}$ sodium oxalate, $0.35 \mathrm{mmol}$ sodium benzoate and $0.05 \mathrm{mmol}$ succinate buffer $\mathrm{pH}$ 2.5. Sample volume and linearity were $5 \mu \mathrm{l}$ and $500 \mathrm{mg} / \mathrm{dl}$, respectively. Standard used was albumin at $100 \mathrm{mg} / \mathrm{dl}$ concentration. In this method $25 \mathrm{mg} / \mathrm{l}$ of sodium dodecyl sulfate was added to the reagent to modify protein reactivities so that the chromogenicity of human gamma globulins is the same as that of albumin.

Method 3 (M3) is a turbidimetric method for the determination of urine total protein using tichloroacetic acid (TCA) according to the method of Henry et al. ${ }^{[17]}$. Reagents were, TCA $0.75 \mathrm{~mol} / \mathrm{l}$, sodium chloride 0.15 $\mathrm{mol} / \mathrm{l}$ and protein standard which is any clear normal human serum with known total protein content (it was $7.5 \mathrm{~g} / \mathrm{dl}$ in our study). Sample volume is $250 \mu \mathrm{l}$. Linearty is $110 \mathrm{mg} / \mathrm{dl}$.

Method 4 (M4) is a turbidimetric immunoassay for urine albumin according to the method of Medcalf et al. ${ }^{[18]}$ (Spectrum, Egypt). Reagents were as follow 1) buffer saline $(9.0 \mathrm{~g} / \mathrm{l})$, accelerator, and sodium azide $(0.95 \mathrm{~g} / \mathrm{l}) .2)$ phosphate buffered saline, polyclonal goat anti-human albumin, and sodium azide $(0.95 \mathrm{~g} / \mathrm{l})$.

Urine protein electrophoresis was performed on agarose gel by a kit technique of Hellabio (Greece) ${ }^{[19-21]}$. Random non-concentrated urine samples were used. Reagents were 1) agarose gel in Tris-acidic buffer, 2) electrophoresis buffer: Tris-acidic buffer $\mathrm{pH} 8.6 \pm 0.2,3$ ) Staining solution: Amido Black solution, 4) Gel blotter strips: thin filter paper strips, and 5) Distaining solution: $10 \%$ acetic acid. After applying $(5 \mu \mathrm{l})$ the urine samples across the corresponding slits, the gel was placed on the gel carrier with the gel upstairs and the samples on the cathodic side (-) then the gel was put in the tank. The tank then connected to the power supply and run 20 minutes /120 volts. The gel then dried completely and stained with protein staining solution. The gel then distained in three distaining solution bath. Finally the gel is dried again and results evaluated by a densitometer using 520-600 nm filter. Instruments used were: Helena scanner model 0280, Titan power supply and Helena oven and chamber. A urine sample from a patient with a known multiple protein bands was used as a positive control to confirm the appropriate separation of different urine protein fractions. The urine was separated in aliquots and stored at $-20^{\circ} \mathrm{C}$. 
Table (1): Demographic characteristics of the study population.

\begin{tabular}{|c|c|c|}
\hline \multicolumn{2}{|l|}{ No of SLE $^{1}$ patients } & 84 \\
\hline \multicolumn{2}{|l|}{ Male / Female } & $0 / 84$ \\
\hline \multicolumn{2}{|c|}{$\begin{array}{l}\text { Age at diagnosis }\left(\text { mean } \pm \mathrm{SD}^{2}\right) \\
\text { Range }\end{array}$} & $\begin{array}{c}28.1 \pm 8.4 \\
17-55 \text { years }\end{array}$ \\
\hline \multicolumn{2}{|c|}{$\begin{array}{l}\text { Onset of SLE }(\text { mean } \pm \text { SD }) \\
\text { Range }\end{array}$} & $\begin{array}{c}4.9 \pm 2.3 \\
1-10 \text { years }\end{array}$ \\
\hline \multicolumn{2}{|l|}{ Urine samples } & Random \\
\hline \multirow{4}{*}{$\begin{array}{l}\text { Urine protein in all } \\
\text { patients }{ }^{3}(\text { mean } \pm S D)\end{array}$} & M1 & $2.8 \pm 2.7$ \\
\hline & M2 & $2.1 \pm 1.7$ \\
\hline & M3 & $1.6 \pm 1.3$ \\
\hline & M4 & $1.5 \pm 1.4$ \\
\hline
\end{tabular}

${ }^{1}$ Systemic lupus Erythematosus. ${ }^{2}$ Standard deviation. ${ }^{3}$ Urine protein as determined by protein/creatinine ratio by three methods (M1, M2 and M3) and albumin/creatinine by the method M4.

The Westergren ${ }^{[22]}$ method was used for the determination of the erythrocyte sedimentation rate. Urine creatinine was determined using the Jaffe colorimetric method ${ }^{[23]}$ by a kit obtained from Egychem (Egypt).

Statistical analysis: All statistical analysis was carried out using the SPSS 11.0 program (Microsoft software).

\section{Results and discussion}

This study was performed on 84 urine samples with known proteinuria from patients with SLE. After electrophoretic separation of these urine samples we found an albumin band only in $57.1 \%$ (48/84), both albumin and globulin (a small alpha 2-globulin) bands in $40.5 \%$ (34/84) and only the same globulin band in $2.4 \%$ (2/84) (Table 2 and Figs. $1 \&$ 2). The percentages of the globulin fractions of the total protein were $100 \%$, $10 \%, 9.5 \%, 7 \%, 5 \%$ and $2 \%$ in $2,4,4,8,4$ and 12 urine samples, respectively.

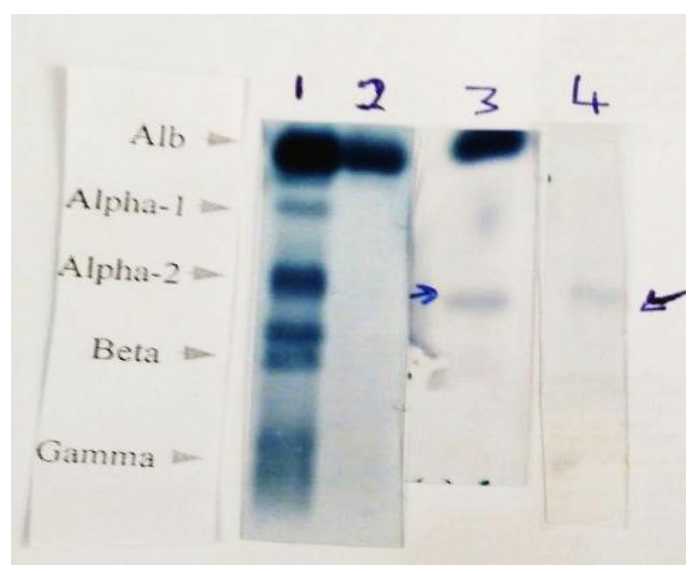

Fig (1): Pathological urine patterns indicating the source of proteinuria. Lane 1, control urine sample showing multiple bands. Lane 2, Glomerular proteinuria with albumin band only. Lane 3, Mixed (glomerular and tubular) proteinuria showing albumin and $\alpha 2$-globulin bands. Lane 4, Tubular proteinuria showing $\alpha 2$-globulin band and no albumin.

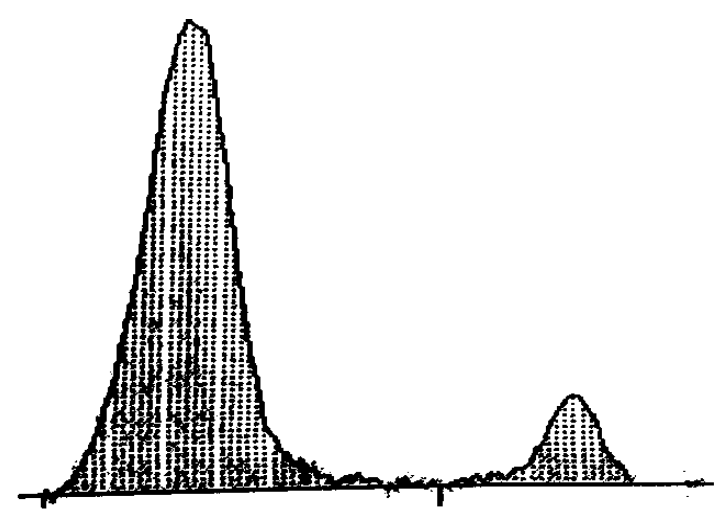

Fig (2): A densitometric scan of a urine sample with mixed proteinuria. The large lane (arrow) indicates albumin and the small one (star) represents $\alpha 2$ globulin.

Urine protein electrophoresis provides distinctive patterns that can indicate the source of proteinuria ${ }^{[4,19]}$. Patients showing the albumin band only represent a pure glomerular disease, since in this condition large proteins pass more readily through the glomerulus. Because of the relatively great concentration of serum albumin, glomerular disease produces abundant albuminuria. The smaller globulins are reabsorbed by the kidney tubules, which behave normally. However, in pure tubular proteinuria these small globulins (polyclonal free light chains and $\alpha 2$-microglobulins) are not reabsorbed and appear in the urine. When mixed tubular and glomerular proteinuria occurs, the two patterns are superimposed ${ }^{[4]}$. Secondary SLE TIN is frequent, but its frequency and severity correlate with the class of the associated lupus glomerulonephritis (GN). Although the presence of underlying GN may mask its clinical manifestation, secondary SLE TIN has a major prognostic implication for the renal outcome. Primary SLE TIN, which occurred in $2.4 \%$ of patients in our study, is rare and has a rather uniform and distinctive clinical manifestation including acute kidney injury with 
Table (2): Prevalence of albumin and globulin bands found in the urine of 84 SLE patients after electrophoresis

\begin{tabular}{|l|ccc|}
\hline Fraction & Albumin only & Albumin and $\alpha 2$-globulin & $\alpha 2$-globulin only \\
\hline Number $(\%)$ & $48 / 84(57.1 \%)$ & $34 / 84(40.5 \%)$ & $2 / 84(2.4 \%)$ \\
\hline
\end{tabular}

no or mild proteinuria. It responds well to steroid and usually carries a good prognosis ${ }^{[24-26]}$. Thus, identifying the source of proteinuria has a great prognostic value. In our study, the presence of both albumin and $\alpha 2$-globulin (mixed tubular and glomerular proteinuria) was associated with longer disease duration $(\mathrm{P}<0.02)$ compared with patients with albumin fraction only (pure glomerular), while the age of onset, ESR and P/C (as determined by M3) ratio were not statistically significant (Table 3). Indeed, the observation of longer disease duration is very important since it confirms the observations ${ }^{[\mathbf{2 6 , 2 7 ]}}$ that the tubular injury occurs more frequently as secondary to glomerulonephritis rather than primary.

The mean $( \pm \mathrm{SD})$ of the disease duration, age at onsetand ESR of the 2 patients with pure tubular proteinuria were $3.5 \pm 0.7,26 \pm 8.4$ and 35 35.7 , respectively. Their $\mathrm{P} / \mathrm{C}$ ratio (Table 4) were mildly elevated, 0.36 and $0.4,0.37$ and 0.39 , and 0.38 and 0.4 , for M3, M2 and M1 methods, repectively. Indeed, it is in agreement with the observation that tubular injury always produce mild proteinuria ${ }^{[4,27]}$. The albumin/globulin ratios of the same urine samples were normal (0.01 and 0.008). Thus, it is not recommended to use albumin/creatinine ratio instead of $\mathrm{P} / \mathrm{C}$ ratio for the detection of proteinuria in SLE since samples with globulin proteinuria, thought rare, will be lost .On the other hand, there was a good comparability of the P/C ratio of the 3 methods (M1, M2 and M3), which may suggest a similar ability to detect this urine globulin band (Table 4).

No single particular method for urine protein determination is consistently superior to another. Whichever method is chosen in the laboratory should be used for all samples on that patient in order to provide consistent data when following a patient. If two different methods are used on samples taken at two different times, any apparent increase or decrease may be caused by variability in the methods rather than a change in the patient's condition [4]. With these words we start the second part of this study. In this part we investigated the comparability of two colorimetric methods (M1 and M2) and a turbidimetric method (M3). Both the colorimetric methods are based on the ability of pyrogallol red to bind to proteins, the differences are in the standard used (albumin/globulin for M1 and albumin for M2), linearity (longer for M2) and the addition of sodium dodecyl sulfate in M2 to increase accuracy in measuring proteins other than albumin. M3 method based on the ability of TCA for the precipitation of different proteins. Before discussing the comparability of protein concentration of the methods M1, M2 and M3, we want to mention that we used protein concentration ratios and the linear regression analysis as they were recommended by the Analytical Biochemistry Group, School of Sciences, The University of Sunderland ${ }^{[28]}$ for comparing different analytical methods.

Table (3): Comparison between disease duration, age at onset, ESR and P/C ratio of patients with proteinuria showing albumin fraction only and those showing both albumin and $\alpha 2$-globulin fractions

\begin{tabular}{|l|c|c|c|}
\hline & $\begin{array}{c}\text { Pure glomerular } \\
\text { proteinuria } \\
\mathbf{( N ~ 4 8 )}\end{array}$ & $\begin{array}{c}\text { Mixed tubular and } \\
\text { glomerular proteinuria } \\
\mathbf{( N ~ 3 4 )}\end{array}$ & Significance \\
\hline Disease duration (mean \pm SD) & $4.0 \pm 1.46$ & $5.67 \pm 2.65$ & $\mathrm{P}<0.02$ \\
\hline Age at onset (mean \pm SD) & $29.7 \pm 9.90$ & $26.1 \pm 5.30$ & $\mathrm{NS}$ \\
\hline ESR* (mean \pm SD) & $38.9 \pm 18.5$ & $48.4 \pm 25.4$ & $\mathrm{NS}$ \\
\hline Protein/creatinine ratio (mean \pm SD) & $1.77 \pm 1.72$ & $1.48 \pm 0.801$ & $\mathrm{NS}$ \\
\hline
\end{tabular}

*Erythrocyte sedimentation rate .Results are significant at $\mathrm{p}<0.05$.) ( Data of the 2 urine samples with primary tubulointerstitial injury are not included in this Table).

Table (4): Protein/creatinine ratio of the 2 urine samples with $\alpha 2$-globulin band only (pure tubular) by the 4 methods of urine protein determination

\begin{tabular}{|c|c|c|}
\hline P/C ratio & Sample 1 & Sample 2 \\
\hline M1 & 0.38 & 0.4 \\
\hline M2 & 0.37 & 0.39 \\
\hline M3 & 0.36 & 0.4 \\
\hline M4 & 0.01 & 0.008 \\
\hline
\end{tabular}

$\mathrm{P} / \mathrm{C}$ ratio, protein/creatinine ratio. 
Table (5): Tukey HSD post hoc multiple comparisons between the mean $\mathrm{P} / \mathrm{C}^{*}$ ratio of our 84 urine samples as determined by the methods M1, M2 and M3.

\begin{tabular}{|cccc|}
\hline & M1 & M2 & M3 \\
\hline P/C $/ C^{*}$ ratio Mean $\left( \pm \mathrm{SD}^{* *}\right)$ & $2.8 \pm 2.7$ & $2.1 \pm 1.7$ & $1.6 \pm 1.3$ \\
$P$ vs $M 2$ & $N S^{* * * *}$ & -- & $N S$ \\
$P$ vs $M 1$ & & & $<0.01^{* * * *}$ \\
\hline protein/creatinine ratio & ${ }^{* *}$ standard deviation & ${ }^{* * *}$ Non-significant & ${ }^{* * * *}$ Results are significant at $\mathrm{p}<0.05$
\end{tabular}

The M3/M1, M3/M2 and M2/M1 ratios (ratios are that of the mean of the corresponding values for urine protein in $\mathrm{mg} / \mathrm{dl}$ ) were $0.78 \pm 0.31,0.75 \pm 0.19$ and $0.79 \pm 0.19$, respectively. This means that the comparability of the 3 methods is not good (the ratio is not reaching 1.0 or 0.9 ). The linear regression analysis also indicated the inadequate agreement between the 3 methods as follow: $\mathrm{Y}(M 1)=1.7 \mathrm{X}(M 3)+27.5, \mathrm{Y}(M 2)$ $=1.4 \mathrm{X}(M 3)-21.6$ and $\mathrm{Y}(M 1)=1.2 \mathrm{X}(M 2)+50.6$. The mean values of $\mathrm{P} / \mathrm{C}$ ratio of the 3 methods showed statistically significant differences by one way ANOVA ( $\mathrm{p}<0012$ ). Post-hoc multiple comparisons (Tukey HSD) between M1, M2 and M3 are presented in Table 5. The observed difference between methods used in the present study for urine protein determination should be considered while evaluating the ability of $\mathrm{P} / \mathrm{C}$ ratio to replace protein in 24 hour urine. Thus, the reported conflicting results ${ }^{[10-14]}$ could be, at least in part, due to variability between methods used for urine protein determination.

In order to compare the values of total protein measured by the 3 methods with urine albumin (determined by M4) we obtained the corresponding albumin values after removing the percentage of globulin fraction of each total protein value. The M4/M1, M4/M2 and M4/M3 ratios of the corresponding values for urine protein (albumin) in $\mathrm{mg} / \mathrm{dl}$ were $0.69 \pm 0.27,0.78 \pm 0.3$ and $0.91 \pm 0.26$, respectively. These ratios are showing a good agreement between M4 and M3. Regression analysis also confirmed the good agreement of M3 with M4 $(\mathrm{YM} 3=0.99 \mathrm{XM} 4+6.5)$ and the lower one with M1 and $\mathrm{M} 2(\mathrm{Y} M 1=1.8 \mathrm{XM} 4+16.756301$ and $\mathrm{YM} 2=1.4 \mathrm{XM} 4$ 10.02) (Table 6 and Figs. 3, 4 \& 5).

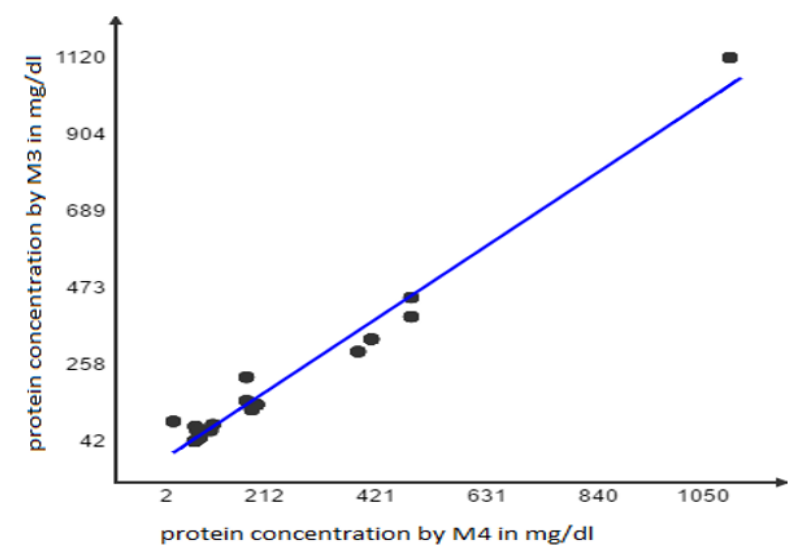

Fig (3): Correlation plots of the M3 and M4 protein concentration values.

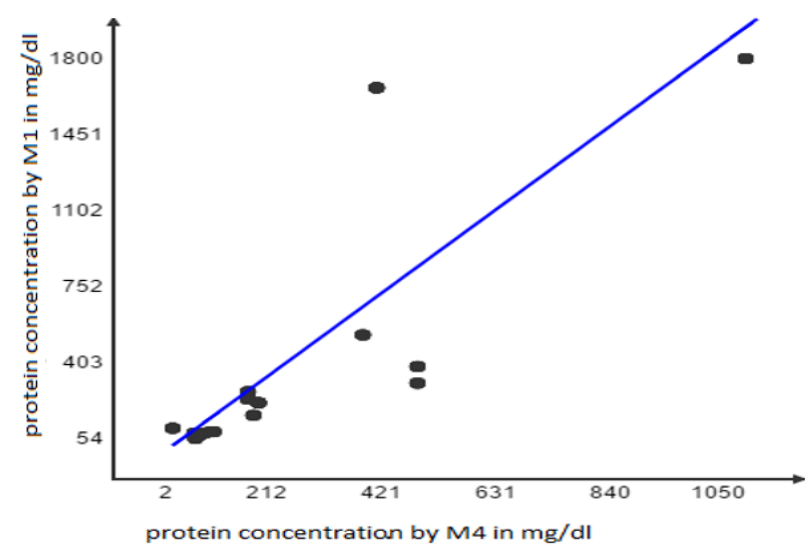

Fig (4): Correlation plots of the M1and M4 protein concentration values.

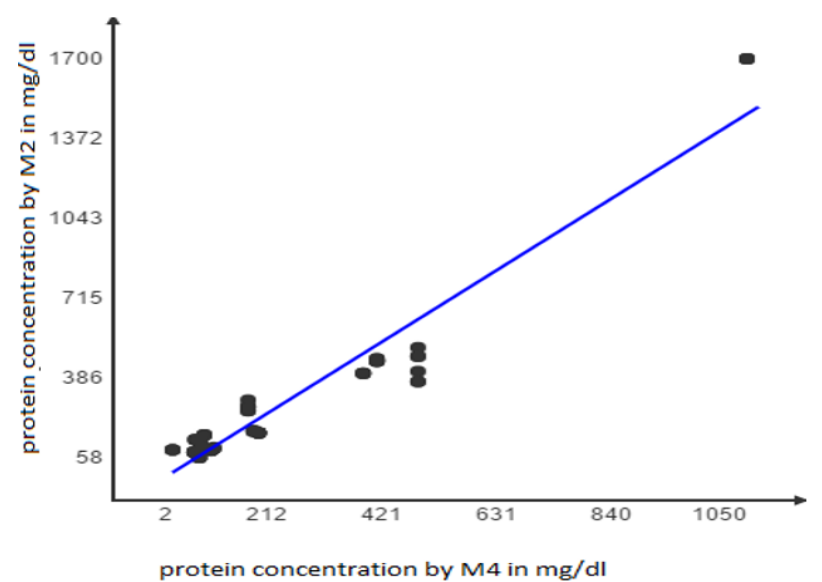

Fig (5): Correlation plots of the M2 and M4 protein concentration values.

However, it must be noted that the agreement with M4 is much better for M2 than M1. The accurate quantification of pure albumin by the TCA turbidimetric method was noted by Nishi and Elin ${ }^{[29]}$ and by Moela et al. ${ }^{[30]}$. Marshal and Williams ${ }^{[28]}$ used the TCA turbidity as a reference method in comparing the effect of the type of standard on the result of pyrogallol colorimetric method for the detection of urine protein. The TCA/pyrogallol ratio changed from 0.81 to 1.06 with the use of human urine protein as a standard instead of albumin or albumin/globulin. This may explain the low comparability of our pyrogallol methods (M1 and M2) 
Table (6): Correlation between M1, M2, M3 (Y) and M4 (X) for the detection of urine protein (albumin) of 84 patients with SLE.

\begin{tabular}{|cccccc|}
\hline Method & $\begin{array}{c}\text { Range } \\
\mathbf{m g} / \mathbf{d l}\end{array}$ & $\begin{array}{c}\text { Mean } \\
\mathbf{m g} / \mathbf{d l}\end{array}$ & $\begin{array}{c}\text { Median } \\
\mathbf{m g} / \mathbf{d l}\end{array}$ & Slope & $\begin{array}{c}\text { Intercept } \\
\mathbf{m g} / \mathbf{d l}\end{array}$ \\
\hline M1 & $54-1800$ & 400.7 & 165 & 1.8 & 16.7 \\
M2 & $58-1700$ & 284 & 160 & 1.4 & -10.02 \\
M3 & $42-1120$ & 215.2 & 134 & 0.99 & 6.5 \\
\hline
\end{tabular}

with M3 and M4. Whether the use of urine protein as a standard will improve the comparability of the methods remains to be identified. It must be noted that one of the difficulties in defining the measured is that the composition of albumin molecules in urine is complex and varies significantly, even between healthy individuals. In serum, several factors may produce conformational changes to albumin which in turn affect the filtration rate at the glomerulus. Moreover, albumin in urine is exposed to a wider range of $\mathrm{pH}$ and ionic strength than found in plasma. Other potentially modifying factors include the presence of high concentrations of urea, glucose and ascorbate, and cleavage by peptidases. All these change in albumin in serum and urine might be specific for each disease ${ }^{[31]}$. Thus the validity of a method in determining albumin in a certain disease should not be applied to other diseases.

\section{Conclusion}

Urine protein electrophoresis of 84 patients with SLE revealed 3 patterns which identified the source of proteinuria. Patterns were pure glomerular, mixed glomerular and tubular and pure tubular. Comparison with renal biopsy is needed to evaluate urine protein electrophoresis as a non-invasive technique for detecting the source of proteinuria in SLE. The use of albumin/globulin ratio for the detection of proteinuria in SLE is not recommended since it will give false negative results in patients with pure tubular proteinuria. Lack of good agreement was found between methods of urine protein determination. Consequently, the effect of the methods of protein determination should be considered while interpreting the conflicting correlations between $\mathrm{P} / \mathrm{C}$ ratio and the 24 hour protein test .Comparison with an immunoassay method for the detection of urine albumin (M4) revealed a good agreement only with the TCA based turbidimetric method (M3).

Acknowledgment: We would like to thank Dr. Samia A. Abdo MD, consultant of internal medicine, Faculty of Medicine, Ain Shams University, for her role in the clinical part of this study.

\section{References}

1) Satoskar, A. A., Brodsky, S. V., Nadasdy, G., Bott1, C., Rovin, B., Hebert, L. and Nadasdy, T. (2011). Discrepancies in glomerular and tubulointerstitial/vascular immune complex IgG subclasses in lupus nephritis. Lupus, 20:1396-1403.
2) Dhingra, S., Qureshi, R., Abdellatif, A., Gaber, L. W. and Truong, L. D. (2014). Tubulointerstitial nephritis in systemic lupus erythematosus: innocent bystander or ominous presage. Histol Histopathol., 29(5):553-565.

3) Moroni, G., Depetri, F. and Ponticelli, C. (2016). Lupus nephritis: When and how often to biopsy and what does it mean? J Autoimmun., 24:1-14.

4) Keren, D. F. (2003). Examination of urine for Proteinuria in Protein Electrophoresis in: Clinical Diagnosis David F Keren-PP: 216, First published ,Great Britain, Hodder Arnold, a member of the Hodder Headline Group, 338 Euston Road, London NW1 3BH.

5) Bottini, P.V., Ribeiro-Alves, M. A. and Garlipp, C. R. (2002). Electrophoretic pattern of concentrated urine: Comparison between 24-hour collection and random samples. Am. J. Kidney Dis., 39:e2.1-e2.4.

6) Levinson, S. S. (2000). Urine protein electrophoresis and immunofixation electrophoresis supplement one another in characterizing proteinuria. Ann Clin Lab Sci., 30:79-84.

7) Liang, M. H., Schur, P. H., Fortin, P., St.Clair, E. W., Balow, J. E., Costenbader, K., Crofford, L., de Pablo, P., Dooley, M. A., Finckh, A., Gordon, C. P., Lundberg, I. E., Meyrier, A., Nived, O., Ponticelli, C., Schneider, M. K., Singh, A. and Wallace, D. J. (2006). The American College of Rheumatology response criteria for proliferative and membranous renal disease in systemic lupus erythematosus clinical trials. Arthritis Rheum, 54(2):421-432.

8) Bertsias, G. K., Tektonidou, M., Amoura, Z., Aringer, M., Bajema, I., Berden, J. H., Boletis, J., Cervera, R., Dörner, T., Doria, A., Ferrario, F., Floege, J., Houssiau, F. A., Ioannidis, J. P., Isenberg, D. A., Kallenberg, C. G., Lightstone, L., Marks, S. D., Martini, A., Moroni, G., Neumann, I., Praga, M., Schneider, M., Starra, A., Tesar, V., Vasconcelos, C., van Vollenhoven, R. F., Zakharova, H., Haubitz, M., Gordon, C., Jayne, D. and Boumpas, D. T. (2012). Joint European League Against Rheumatism and European Renal Association-European Dialysis and Transplant Association (EULAR/ERA-EDTA) recommendations for the management of adult and paediatric lupus nephritis. Ann Rheum Dis., 71(11):1771-1182.

9) Ginsberg, J. M., Chang, B. S., Matarese, R. A. and Garella, S. (1983). Use of single voided urine samples to estimate quantitative proteinuria. $\mathrm{N}$ Eng $\mathrm{J}$ Med, 309(25):1543-1546. 
10) Medina-Rosas, J., Yap, K. S., Anderson, M., Su, J. and Touma, Z. (2016). Utility of Urinary Protein Creatinine Ratio and Protein Content in a 24 HourUrine Collection in Lupus: Systematic Review and Meta-Analysis. Arthritis Care Res (Hoboken). 68(9):1310-1319.

11) Bland, J. M. and Altman, D. G. (1995). Comparing two methods of clinical measurement: a personal history. Int J Epidemiol, 24(1):S7-14.

12) Bland, J. M. and Altman, D. G. (2003). Applying the right statistics: analyses of measurement studies. Ultrasound Obst Gynecol, 22(1):85-93.

13) Chitalia, V. C., Kothari, J., Wells, E. J., Livesey, J. H., Robson, R. A., Searle, M. and Lynn, K. L. (2001). Costbenefit analysis and prediction of 24hour proteinuria from the spot urine proteincreatinine ratio. Clin Nephrol, 55(6):436-447.

14) Restrepo-Escobar, M. (2012). Correlation versus agreement in two methods for urinary protein quantification in lupus nephritis. Lupus 21(11):1259.

15) Watanabe, N., Ohkubo, A., Ohsawa, S. and Tokuda, K. (1986). Urinary protein as measured with a pyrogallol red-molybdate complex, manually and in a Hitachi 726 automated analyzer. Clin Chem, 32(8):1551-1554.

16) Orsonneau, J., Douet, P., Massoubre, C., Lustenberger, P. and Bernard, S. (1989). An improved pyrogallolred-molybdatemethod for determining total urinary protein .Clin Chem, 35(11):2233-2236.

17) Henry, R. J., Sobel, C. and Segalove, M. (1956). Turbidimetric determination of proteins with sulfosalicylic and trichloracetic acids. Proc SOC Exp Biol Med, 92:748-751.

18) Medcalf, E., Newman, D., Gorman, G. and PrIce, C. (1990). Rapid, Robust Method for Measuring Low Concentrations of Albumin in Urine. Clin Chem., 36(3):446-449.

19) Levinson, S. (2000). Urine Protein Electrophoresis and Immunofixation Electrophoresis Supplement One Another in Characterizing Proteinuria. Annals of Clinical \& Laboratory Science, 30(1):79.

20) Bricon, T., Erlich, D., Bengoufa, D., Dussaucy, M., Garnier, J. and Bousquet, B. (1998). Sodium dodecyl sulfate-agarose gel electrophoresis of urinary proteins: application to multiple myeloma. Clin Chem., 44(6):1191-1197.
21) Laurell, C. B. (1972). Composition and variation of the gel electrophoretic fractions of plasma, cerebrospinal fluid and urine. Scand J Clin Lab Invest, 29(124):71-82.

22) Westergren, A. (1957). Diagnostic tests: the erythrocyte sedimentation rate range and limitations of the technique. Triangle, 3(1):20-25.

23) Jaffe, M. (1886). Über den Niederschlag, welchenPikrinsäre in normalem Harnerzeugt und übereineneue Reaction des Kreatinins. Zeitschriftfür physiologische Chemie. 10(5):391-400.

24) Jeong, H. J., Shin, S. J. and Lim, B. J. (2016). Overview of IgG4_Related tubulointerstitial Nephritis and Its Mimickers. J Pathol Transl Med., 50(1):26-36.

25) Clark, M. R., Trotter, K. and Chang, A. (2015). The pathogenesis and therapeutic Implications of tubulointerstitial inflammation in human lupus nephritis. Semin Nephrol., 35(5):455-464.

26) Dhingra, S., Qureshi, R., Abdellatif, A., Gaber, L. W. and Truong, L. D. (2014). Tubulointerstitial nephritis in systemic lupus erythematosus: innocent bystander or ominous presage Histo Pathol. 29(5):553-565.

27) Yu, F., Wu, L. H., Tan, Y., Li, L. H., Wang, C. L., Wang, W. K., Qu, Z., Chen, M. H., Gao, J. J., Li, Z. Y., Zheng, X., Ao, J., Zhu, S. N., Wang, S. X., Zhao, M. H., Zou, W. Z. and Liu, G. (2010). Tubulointerstitial lesions of patients with lupusnephritis classified by the 2003 International Societyof Nephrology and Renal Pathology Society system. Kidney International, 77:820-829.

28) Marshall, T. and Williams, M. (2000). Total protein determination in urine: elimination of a differential response between the coomassieblue and pyrogallolred protein dye-binding Assays. Clin Chem 46(3):392-398.

29) Nishi, H. and Elin, J. (1985). The three turbidimetric methods for determining total protein compared. Clin Chem., 31(8):1377-1380.

30) Meola, J. M., Vargas, M. A. and Brown, H. H. (1977). Simple procedure for measuring total protein in urine. Clin Chem, 23(6):975-977.

31) Martin, H. (2011). Laboratory measurement of urine albumin and urine total protein in screening for proteinuria in chronic kidney disease. Clin. Biochem. Rev., 32(I):97. 